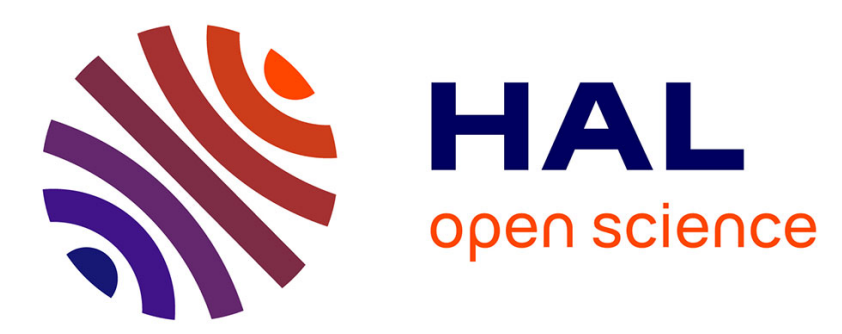

\title{
Association of choroidal IL-17-producing T lymphocytes and macrophages with geographic atrophy
}

Serge Camelo, Sophie Lavalette, Xavier Guillonneau, William Raoul, Florian Sennlaub

\section{- To cite this version:}

Serge Camelo, Sophie Lavalette, Xavier Guillonneau, William Raoul, Florian Sennlaub. Association of choroidal IL-17-producing T lymphocytes and macrophages with geographic atrophy. Ophthalmologica, 2016, 236 (1), pp.53-58. 10.1159/000446587 . inserm-01499605

\section{HAL Id: inserm-01499605 https://www.hal.inserm.fr/inserm-01499605}

Submitted on 31 Mar 2017

HAL is a multi-disciplinary open access archive for the deposit and dissemination of scientific research documents, whether they are published or not. The documents may come from teaching and research institutions in France or abroad, or from public or private research centers.
L'archive ouverte pluridisciplinaire HAL, est destinée au dépôt et à la diffusion de documents scientifiques de niveau recherche, publiés ou non, émanant des établissements d'enseignement et de recherche français ou étrangers, des laboratoires publics ou privés. 


\section{Association of choroidal IL-17-producing T lymphocytes and macrophages}

with geographic atrophy

Serge Camelo, Sophie Lavalette ${ }^{\mathrm{b}}$, Xavier Guillonneau ${ }^{\mathrm{b}}$, William Raoul ${ }^{\mathrm{c}, *}$ and Florian Sennlaub ${ }^{\text {b,* }}$

aAP-HP, Unité de Recherche Clinique Lariboisière Saint-Louis, Paris, France.

b Sorbonne Universités, UPMC Univ Paris 06, INSERM, CNRS, Institut de la Vision, 17 rue Moreau, 75012 Paris, France.

c Université François-Rabelais de Tours, CNRS, GICC UMR 7292, Tours, France

* These authors contributed equally to this work

Correspondence should be addressed to Dr Florian Sennlaub, Institut de la Vision, INSERM UMRS968 - 17 rue Moreau, 75012 Paris, France. Tel: +33153462693 - E-mail:

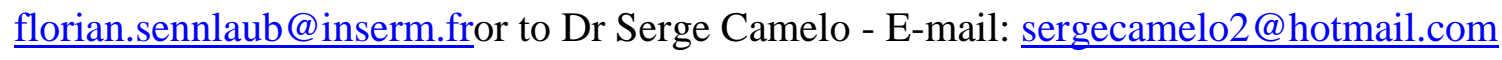




\begin{abstract}
Purpose: To evaluate the presence of interleukin-17 (IL-17)-producing cells in patients with geographic atrophy (GA).

Methods: In this short report, we analyzed IL-17, CD3 and IBA-1 expression by immunohistochemistry on paraffin-embedded sections from 13 donors with a known history of GA, confirmed by fundus appearance and histology, and 7 age-matched control donors. Results and conclusion: we show that IL-17+ cells are found near areas of retinal pigmented epithelium (RPE) atrophy in eyes of GA patients. $\mathrm{IL}-17^{+}$cells mainly localized to $\mathrm{CD} 3^{+}$cells, which identifies $\mathrm{T}$ lymphocytes, as well as IBA- $1^{+}$cells, which identifies mononuclear phagocytes. Therefore IL-17 could be involved in the pathological mechanisms that contribute to degeneration observed in GA.
\end{abstract}

\title{
Keywords
}

Interleulin-17, lymphocytes, CD3, choroid, geographic atrophy, age-related macular degeneration 


\section{Introduction}

Age-related Macular Degeneration (AMD) is a leading cause of irreversible blindness in elderly people in the industrialized world (1). There are two late forms of AMD: the exudative or wet form defined by choroidal neovascularization (CNV) and the slow developing atrophic form known as Geographic Atrophy (GA). There is no efficient therapy for GA at the moment. GA is characterized by choroidalthinning (2)and a slowly expanding lesion of photoreceptor andretinal pigment epithelium (RPE) degeneration and dysfunction (3). GA is a complex multifactorial event influenced by: aging (4), environmental factors such as smoking history (5), oxidative stress $(6,7)$ and geneticpredisposition, particularly haplotypes containing polymorphisms of Complement Factor $\mathrm{H} \quad(\mathrm{CFH})(8)$ andARMS2/HTRA1 (9). Moreover, low grade inflammation (10, 11)and accumulation of mononuclear phagocytes in the subretinal space areclearly associated with $\operatorname{GA}(12,13$, 14).Adaptive immunity probably also play a role in AMD pathophysiology (15). Indeed, 30 years ago, Penfold et al. detected the presence of lymphocytes in the eyes of GA and exudative AMD patients and they proposed that they may play a role in RPE atrophy and breakdown of Bruch's membrane $(16,17)$. Moreover $\mathrm{CD}^{+}$cells have been observed in the choroid of frozen sections of eyes from advanced AMD patients with or without drusen or fibrovascular scar (18). Interestingly, Gregerson et al.(19) showed that cytotoxic CD8 ${ }^{+}$lymphocytes could kill murine RPE cellsin vitro by induction of apoptosis in an antigendependent manner. Faber et al. (20)demonstrated that the presence of $\mathrm{CD}^{+} 6^{+} \mathrm{CD} 28^{-}$memory $\mathrm{T}$ cells in the blood of AMD patients is associated with a3.5 foldincrease of the risk of developing AMD. The risk of AMD is increased up to 13.3 times in the case of persons with enhanced levels of memory $\mathrm{T}$ cells in blood and exhibiting at least one $\mathrm{CFH} \mathrm{H} 402 \mathrm{Y}$ risk allele. 
Interleukin-17 A (IL-17) is a cytokinethat contributes to the pathogenesis of inflammatory and auto-immune diseases $(21,22)$ but its role is not restricted to these pathologies(23). A major source of IL-17 is a lineage of T cells known as CD4 ${ }^{+} \mathrm{T}$ helper 17 cells (Th17 cells) which differ from the Th1 and Th2 subsets (24). IL-17 is secreted by other cell types of innate and adaptive immune systemsnotably macrophages( 25,26$)$. In GA, an increase of IL-17 immuno-positivity has been reported in GA eyes compared to control subjects, but the IL-17-producing cells could not be identified(27). Furthermore, genetic variants of IL-17 have been shown to be associated with $\operatorname{AMD}(28)$, while the reported association of hypo-methylation of the IL-17 receptor(27) was not reproducible in another $\operatorname{study}(29)$.

In this short report, we show that IL- $17^{+}$cells are not found in un-affected donor eyes, but accumulate in the choroid of GA donors near areas of RPE atrophy. They mainly co-localize with CD3 staining, which identifies Tlymphocytes, and IBA-1 staining that identifies cells of the monocyte/macrophage family. IL-17, released from infiltrating immune cells, could play an important role in GA pathogenesis.

\section{Materials and Methods}

\section{Donor Eyes}

Donor eyes with or without a known history of AMD, with GA lesions visible on postmortem fundus photographs confirmed by histological evaluation and controls, were obtained from theMinnesota Lions Eye bank ( 7 control maculae from 7 patients ( 5 men and 2 women), meanage 84+/- 2.6 years; 13 GA donor maculae from 11 different patients (4 men and 7 women), mean age $83.7+/-2.4$ years). Fundus photographs were taken with using a macroscope andadapted camera by the Minnesota Lions Eye bank. Donor eyes without a 
known history of eye diseases and no signs of RPE or retinal lesions were considered as being control eyes. Informed consent was obtained for alldonor eyes from Minnesota Eye bank and experiments conformed to the principles set out inthe WMA Declaration of Helsinki.

\section{Histology and Immunohistochemistry}

The posterior segment was fixed $4 \mathrm{~h}$ in $4 \%$ paraformaldehyde. $8 \mu \mathrm{m}$ horizontal sections of paraffin embedded human tissues crossing the optic nerve and perifovea were cut with amicrotome (Microm Microtech France). The sections were de-paraffinized, by incubation inSafesolv and rehydration was performed in serial baths of alcohol/water. Some sections ofeach sample were stained with toluidin blue for histology. Antigen retrieval was performed inboiling EDTA buffer for 15 minutes. Following inhibition of endogenous peroxidases for 20 minutes in $0.3 \% \mathrm{H} 2 \mathrm{O} 2$ (Sigma $\mathrm{H} 1009,1: 100$ in PBS), sections were blocked with 1\% purified horse or goat serum and then exposed overnight to rat anti-human CD3e (MCA1477, Serotec), goat anti-human IL-17 (AF-317-NA, R\&D systems) or rabbit anti-IBA-1 (Wako). Alexa-fluorescent-conjugated secondary antibody (1:400; Life Technologies) was used to reveal primary antibodies. Sections were counterstained with 4-6-diamino-2-phenylindole (DAPI). They were imaged with a DM5500 microscope (Leica) or a confocal microscope (LSM 710, Zeiss). Alternatively, anti-IL-17 primary antibodies were incubated with peroxidase labeled horse anti-goat IgG (PI-9500) (Vector laboratories) and revealed with peroxidase substrate kit (SK-4600, Vector laboratories). IL-17+ cells were counted in the choroid and retina of central control sections and central section's containing GA lesions and divided by the length of the section for control retina and the length of the GA lesion for AMD eyes (cells/mm). The quantifications were performed on substrate IL17-stained sections. Additionally we performed double labeling of IL-17 and CD3e on all GA sections and IL-17 and IBA-1 staining on 3 sections. Staining that omitted the primary antibodyserved 
as negative controls. Final image processing was performed using Adobe Photoshop(Mountain View). All images are representative of at least 3 stainings performed with similarresults.

\section{Statistical analysis}

Graph Pad Prism 6 (GraphPad Software) was used for data analysis and graphic representation. We analyzed 7 control maculae from 7 patients and 13 GA donor maculae from 11 patients. All values are reported as means \pm SD. Statistical comparisons used non-parametric Mann-Whitney test. $P$-values less than 0.05 were considered statistically significant.

\section{Results and Discussion}

Healthy donor eyes revealed a visible fovea on post-mortem funduscopy and a regularhistology of the parafovea, recognizable by multilayered ganglion cell nuclei (Fig. 1A and $\mathrm{B})$.

GA lesions were visible on post-mortem fundus pictures (Fig. 1C) and confirmed histologically by the missing RPE and thinned photoreceptor cell layer in the lesion of the parafovea (multilayered ganglion cell layer) in the absence of vessels penetrating Bruchs membrane (as observed in neovascular AMD) or a fibroglial scar (Fig. 1D).

InGA sectionscontaining the atrophic lesions (illustrating fundus and histological section in Figure 1, compared to normal donor sections), we identified $\mathrm{IL}-17^{+}$cells by immunohistochemistry. Numerous $\mathrm{IL}-17^{+}$cells were identified in all 13 GA sections, but never in control donor sections (Fig.2A). IL-17 ${ }^{+}$cells were mainly located within the choroid in proximity to the RPE lesion (Fig. 2B to E) and very rarely found in the adjacent retinaor (Fig.2C and G). Quantification of $\mathrm{IL}-17^{+}$cells per millimeter of section show a significant 
increase of $\mathrm{IL}-17^{+}$cells in GA sections compared to control donor sections (Fig.2F) and that they are mainly located in the choroid. (Fig. 2G).

IL-17 can be secreted by different cell types, but notably by T lymphocytes and macrophages (25). Indeed the round nucleus and small cytoplasm of numerous $\mathrm{IL}^{-17^{+}}$cells (Fig. 2E) suggested that T lymphocytes participate in IL-17 production in GA. Confocal microscopy of double immuno-labelling of IL-17 and CD3 (specifically expressed by T cells (30)) confirmed that an important portion part of IL-17-producing cells (Fig. 3B) are $\mathrm{CD}^{+} \mathrm{T}$ lymphocytes (Fig. 3A, merge 3C). Furthermore, double labeling using the anti-IL17 antibody (Fig. 3E and Fig. 3H) and an anti-IBA-1 antibody (monocyte/macrophage marker, Fig. 3D and G, merge $3 \mathrm{~F}$ and I) revealed that a sub-population of macrophages participate in IL-17 expression in GA. In our experiments, approximately $50 \%$ of the infiltrating $\mathrm{IL}-17^{+}$cells corresponded to $\mathrm{CD}^{+} \mathrm{T}$ cells. IBA- $1^{+} \mathrm{IL}-17^{+}$macrophages were less frequentthan $\mathrm{IL}-17^{+} \mathrm{CD} 3^{+} \mathrm{T}$ cells and represented only a small fraction of $\mathrm{IBA}-1^{+}$macrophages (Fig. 3D to F). Nevertheless, future studies are necessary to identify the remaining IL-17 expressing cell types and to elucidate the exact proportions of all the different IL-17-expressing cell populations in GA eyes.

In conclusion, our results indicate that IL-17+ cells are invariably present in GA lesions but not observed in aged-matched control sections confirming earlier studies of increased IL-17 staining in GA $(31,32)$. Our study identifies T lymphocytes as an important source of IL-17 in GA. We also show that IBA- $1^{+}$monocytes/macrophages participate in the IL-17 production in the choroid of GA patients. This local IL-17 production could contribute to the increased IL-17 serum concentration found in AMD patients compared to aged matched controls (33). Moreover our observations suggest that $\mathrm{T}$ cells and monocytes/macrophages could be responsible for the significant elevation of IL-17 mRNA in maculae of eyes from AMD 
patients compared to control eyes (34). It is yet unclear if and how IL-17 contributes to the GA pathological processes. IL-17 has been shown to directly deteriorate RPE in vitro (32, 35). Moreover IL-17 production has been associated with retinal and RPE lesions in the Nrf2/- mice model of AMD (36) in vivo and IL-17 could contribute to RPE degeneration in GA.

\section{Figure Legends}

Figure 1: Post-mortem fundus picture and histology of donor eyes.

Fundus photographs and toluidin blue stained section of a representative control donor (A and B) and a GA patient (C and D). Scale bar: $50 \mu \mathrm{m}$. RPE: retinal pigment epithelium; AZ: atrophic zone.

\section{Figure 2: $\mathrm{IL}_{-17^{+}}$cells accumulate in eyes of GA patients.}

A: IL-17 immuno-staining in the choroid of eye from control donor without degeneration. B and C-E: IL-17 immuno-staining in the retina and choroid of eyes from 2 different GA patients. D: close-up of immuno-staining in C. E: close-up of immuno-staining in D. F: Quantification of $\mathrm{IL}-17^{+}$cells per $\mathrm{mm} 2$ of section in eyes of control donors and GA patients ( $n=7$ and 13 respectively). G: Distribution of IL-17-producing cells per $\mathrm{mm}^{2}$ of section in eyes of GA patients $(n=13)$. Ctrl: eyes from control donor patients without GA; RPE: retinal pigmented epithelium. Arrows indicate red stained IL- $17^{+}$cells. All values are represented as mean \pm SD. Scale bar: $20 \mu \mathrm{m}$ in all images.

Figure 3: $\mathrm{CD3}^{+} \mathrm{T}$ cells and IBA-1 ${ }^{+}$macrophages constitute major IL-17-producing cell types in GA.

A-C: double immuno-staining for IL-17 (A) and CD3e (B, merged image C) in choroid of a 
GA patient. D-F: Low power double immuno-staining for IL-17 (D) and IBA-1 (E, merged image F) in choroid of a GA patient.A sub-population of IBA- $1^{+}$macrophages express IL-17 while several others do not. G-I: Close up of immuno-staining in D-F respectively showing a single IBA- $1^{+}$macrophage expressing IL-17. Arrows indicate double stained cells and stars indicate autofluorescence. Immuno-staining omitting the primary antibodies served as controls; double labeling procedures were performed on at least 3 different samples. Scale bar: $20 \mu \mathrm{m}$ in all images. RPE: retinal pigmented epithelium.

\section{Author contributions}

S.C., W.R. and F.S. designed the study, performed experiments, analyzed data and wrote the paper; S.Land X.G. performed experimentsor analyzed data.

\section{Acknowledgements}

This work was supported by grants from INSERM, ANR Geno 2009 (R09099DS), and ERC starting Grant (ERC-2007 St.G. 210345).

\section{References}

1. Klein R, Peto T, Bird A, Vannewkirk MR. The epidemiology of age-related macular degeneration. Am J Ophthalmol. 2004;137(3):486-95.

2. Lee JY, Lee DH, Lee JY, Yoon YH. Correlation between subfoveal choroidal thickness and the severity or progression of nonexudative age-related macular degeneration. Invest Ophthalmol Vis Sci. 2013;54(12):7812-8.

3. Holz FG, Pauleikhoff D, Klein R, Bird AC. Pathogenesis of lesions in late age-related macular disease. Am J Ophthalmol. 2004;137(3):504-10.

4. Bonilha VL. Age and disease-related structural changes in the retinal pigment epithelium. Clin Ophthalmol. 2008;2(2):413-24.

5. Neuner B, Komm A, Wellmann J, Dietzel M, Pauleikhoff D, Walter J, et al. Smoking history and the incidence of age-related macular degeneration--results from the Muenster Aging and Retina Study (MARS) cohort and systematic review and meta-analysis of observational longitudinal studies. Addict Behav. 2009;34(11):938-47. 
6. Hollyfield JG. Age-related macular degeneration: the molecular link between oxidative damage, tissue-specific inflammation and outer retinal disease: the Proctor lecture. Invest Ophthalmol Vis Sci. 2010;51(3):1275-81.

7. Beatty S, Koh H, Phil M, Henson D, Boulton M. The role of oxidative stress in the pathogenesis of age-related macular degeneration. Surv Ophthalmol. 2000;45(2):115-34.

8. Edwards AO, Ritter R, 3rd, Abel KJ, Manning A, Panhuysen C, Farrer LA. Complement factor $\mathrm{H}$ polymorphism and age-related macular degeneration. Science. 2005;308(5720):421-4.

9. Dewan A, Liu M, Hartman S, Zhang SS, Liu DT, Zhao C, et al. HTRA1 promoter polymorphism in wet age-related macular degeneration. Science. 2006;314(5801):989-92.

10. $\mathrm{Xu} \mathrm{H}$, Chen M, Forrester JV. Para-inflammation in the aging retina. Prog Retin Eye Res. 2009;28(5):348-68.

11. Buschini E, Piras A, Nuzzi R, Vercelli A. Age related macular degeneration and drusen: neuroinflammation in the retina. Prog Neurobiol. 2011;95(1):14-25.

12. Sennlaub F, Auvynet C, Calippe B, Lavalette S, Poupel L, Hu SJ, et al. CCR2(+) monocytes infiltrate atrophic lesions in age-related macular disease and mediate photoreceptor degeneration in experimental subretinal inflammation in $\mathrm{Cx} 3 \mathrm{cr} 1$ deficient mice. EMBO Mol Med. 2013;5(11):1775-93.

13. Raoul W, Feumi C, Keller N, Lavalette S, Houssier M, Behar-Cohen F, et al. Lipidbloated subretinal microglial cells are at the origin of drusen appearance in CX3CR1-deficient mice. Ophthalmic Res. 2008;40(3-4):115-9.

14. Gupta N, Brown KE, Milam AH. Activated microglia in human retinitis pigmentosa, late-onset retinal degeneration, and age-related macular degeneration. Exp Eye Res. 2003;76(4):463-71.

15. Camelo S. Potential Sources and Roles of Adaptive Immunity in Age-Related Macular Degeneration: Shall We Rename AMD into Autoimmune Macular Disease? Autoimmune Dis. 2014;2014:532487.

16. Penfold P, Killingsworth M, Sarks S. An ultrastructural study of the role of leucocytes and fibroblasts in the breakdown of Bruch's membrane. Aust J Ophthalmol. 1984;12(1):23-31. 17. Penfold PL, Killingsworth MC, Sarks SH. Senile macular degeneration: the involvement of immunocompetent cells. Graefes Arch Clin Exp Ophthalmol. 1985;223(2):6976.

18. Ezzat MK, Hann CR, Vuk-Pavlovic S, Pulido JS. Immune cells in the human choroid. Br J Ophthalmol. 2008;92(7):976-80.

19. Gregerson DS, Lew KL, McPherson SW, Heuss ND, Ferrington DA. RPE cells resist bystander killing by CTLs, but are highly susceptible to antigen-dependent CTL killing. Invest Ophthalmol Vis Sci. 2006;47(12):5385-94.

20. Faber C, Singh A, Kruger Falk M, Juel HB, Sorensen TL, Nissen MH. Age-related macular degeneration is associated with increased proportion of CD56(+) T cells in peripheral blood. Ophthalmology. 2013;120(11):2310-6.

21. Ouyang W, Kolls JK, Zheng Y. The biological functions of T helper 17 cell effector cytokines in inflammation. Immunity. 2008;28(4):454-67.

22. Steinman L. A brief history of $T(H) 17$, the first major revision in the $T(H) 1 / T(H) 2$ hypothesis of T cell-mediated tissue damage. Nat Med. 2007;13(2):139-45.

23. Yang B, Kang H, Fung A, Zhao H, Wang T, Ma D. The Role of Interleukin 17 in Tumour Proliferation, Angiogenesis, and Metastasis. Mediators Inflamm. 2014;2014:623759.

24. Miossec P, Kolls JK. Targeting IL-17 and TH17 cells in chronic inflammation. Nat Rev Drug Discov. 2012;11(10):763-76.

25. Iwakura Y, Ishigame H, Saijo S, Nakae S. Functional specialization of interleukin-17 family members. Immunity. 2011;34(2):149-62. 
26. Hirota K, Ahlfors H, Duarte JH, Stockinger B. Regulation and function of innate and adaptive interleukin-17-producing cells. EMBO Rep. 2011;13(2):113-20.

27. Wei L, Liu B, Tuo J, Shen D, Chen P, Li Z, et al. Hypomethylation of the IL17RC promoter associates with age-related macular degeneration. Cell Rep. 2012;2(5):1151-8.

28. Zhang S, Liu Y, Lu S, Cai X. Genetic Variants of Interleukin 17A Are Functionally Associated with Increased Risk of Age-Related Macular Degeneration. Inflammation. 2014.

29. Oliver VF, Franchina M, Jaffe AE, Branham KE, Othman M, Heckenlively JR, et al. Hypomethylation of the IL17RC promoter in peripheral blood leukocytes is not a hallmark of age-related macular degeneration. Cell Rep. 2014;5(6):1527-35.

30. Reinherz EL, Meuer S, Fitzgerald KA, Hussey RE, Levine H, Schlossman SF. Antigen recognition by human $\mathrm{T}$ lymphocytes is linked to surface expression of the T3 molecular complex. Cell. 1982;30(3):735-43.

31. Chan CC, Shen D, Cao X, Wang V, Wang Y, Tuo J. Expression Of IL-17 In Eyes Of Age-related Macular Degeneration. ARVO abstract. 2011:1228.

32. Ardeljan D, Wang Y, Park S, Shen D, Chu XK, Yu CR, et al. Interleukin-17 retinotoxicity is prevented by gene transfer of a soluble interleukin-17 receptor acting as a cytokine blocker: implications for age-related macular degeneration. PLoS One. 2014;9(4):e95900.

33. Liu B, Wei L, Meyerle C, Tuo J, Sen HN, Li Z, et al. Complement component C5a promotes expression of IL-22 and IL-17 from human T cells and its implication in age-related macular degeneration. J Transl Med. 2011;9:1-12.

34. Chan CC, Ardeljan D. Molecular pathology of macrophages and interleukin-17 in agerelated macular degeneration. Adv Exp Med Biol. 2014;801:193-8.

35. Chen Y, Yang P, Li F, Kijlstra A. The effects of Th17 cytokines on the inflammatory mediator production and barrier function of ARPE-19 cells. PLoS One. 2011;6(3):e18139.

36. Zhao Z, Xu P, Jie Z, Zuo Y, Yu B, Soong L, et al. gammadelta T cells as a major source of IL-17 production during age-dependent RPE degeneration. Invest Ophthalmol Vis Sci. 2014. 